\title{
Breinbrekers: de januskop van psychofarmaca
}

Citation for published version (APA):

Ramaekers, J. G. (2009). Breinbrekers: de januskop van psychofarmaca. Maastricht University. https://doi.org/10.26481/spe.20090619jr

Document status and date:

Published: 19/06/2009

DOI:

10.26481/spe.20090619jr

Document Version:

Publisher's PDF, also known as Version of record

\section{Please check the document version of this publication:}

- A submitted manuscript is the version of the article upon submission and before peer-review. There can be important differences between the submitted version and the official published version of record.

People interested in the research are advised to contact the author for the final version of the publication, or visit the DOI to the publisher's website.

- The final author version and the galley proof are versions of the publication after peer review.

- The final published version features the final layout of the paper including the volume, issue and page numbers.

Link to publication

\footnotetext{
General rights rights.

- You may freely distribute the URL identifying the publication in the public portal. please follow below link for the End User Agreement:

www.umlib.nl/taverne-license

Take down policy

If you believe that this document breaches copyright please contact us at:

repository@maastrichtuniversity.nl

providing details and we will investigate your claim.
}

Copyright and moral rights for the publications made accessible in the public portal are retained by the authors and/or other copyright owners and it is a condition of accessing publications that users recognise and abide by the legal requirements associated with these

- Users may download and print one copy of any publication from the public portal for the purpose of private study or research.

- You may not further distribute the material or use it for any profit-making activity or commercial gain

If the publication is distributed under the terms of Article $25 \mathrm{fa}$ of the Dutch Copyright Act, indicated by the "Taverne" license above, 
Breinbrekers: de Januskop van psychofarmaca 


\section{Colofon}

Foto omslag: buste van Janus Bifrons, Vaticaan museum

Ontwerp en print: Océ Business Services, Maastricht

ISBN: $978-90-5681-312-3$

NUR: 770

Alle rechten voorbehouden. Niets uit deze uitgave mag worden verveelvoudigd, opgeslagen in een geautomatiseerd gegevensbestand of openbaar gemaakt worden, zonder voorafgaande schriftelijke toestemming van de auteur of uitgever. 


\section{Breinbrekers: de Januskop van psychofarmaca}

Rede uitgesproken bij de aanvaarding van het bijzonder hoogleraarschap Gedragstoxicologie van Geneesmiddelen en Drugs aan de Universiteit Maastricht,

Maastricht, 19 Juni 2009

Door Prof. dr. J.G. Ramaekers 
Mijnheer de Rector Magnificus,

Zeer gewaardeerde toehoorders,

\section{Gedragstoxicologie van geneesmiddelen en drugs}

Hebt $U$ wel eens last van een dipje? Komt $U$ uw bed niet meer uit? Bent $\cup$ niet meer gemotiveerd op uw werk en heeft $U$ geen zin om na uw werk het huis te poetsen? Geen nood, er is nu een nieuw geneesmiddel op de markt dat uw motivatie in een klap weer kan herstellen! Dat nieuwe geneesmiddel heet Strivor! Kijkt $U$ maar even naar het volgende reclamefilmpje.

Strivor is natuurlijk een fictief geneesmiddel tegen een motivatiegebrek stoornis. Het filmpje is ontwikkeld door de Belgische consumentenbond en is een ludieke persiflage op standaard reclamecampagnes zoals die vooral in de VS op televisie te zien zijn. In deze filmpjes wordt de aandoening eerst sterk gedramatiseerd en vervolgens wordt de therapeutische werking lang en breed uitgemeten. Aan de mogelijke bijwerkingen wordt echter weinig aandacht besteed. Alleen aan het einde van het reclamefilmpje komen de mogelijke klachten in sneltreinvaart voorbij. En toch zijn deze bijwerkingen soms belangrijker dan de therapeutische werking van een geneesmiddel. In het geval van Strivor vallen de bijwerkingen nog wel mee. Een beetje winderigheid en seksuele stimulatie kunnen over het algemeen geen kwaad, maar hoe zit het met lusteloosheid? Is dat niet juist een bijwerking die de klinische bruikbaarheid sterk verminderd? Met deze vraag begeven we ons direct op het wetenschapsterrein van de gedragstoxicologie.

De gedragstoxicologie richt zich op ongewenste effecten van geneesmiddelen en drugs op psychologische functies. Psychofarmaca kunnen een reeks van ongewenste bijwerkingen veroorzaken, zoals sufheid, vermindering van cognitieve vermogens, slaapstoornissen, motorische en emotionele stoornissen en lethargie, die ertoe kunnen leiden dat hun gebruikers minder goed functioneren in het dagelijkse leven of aan een hoger risico op ongevallen worden blootgesteld. Deze bijwerkingen kunnen dus schadelijk zijn voor het vermogen van gebruikers om op een normale en efficiënte manier te handelen. Kortom, de meeste psychofarmaca, of het nu gaat om geneesmiddelen of drugs, hebben een Januskop. Ze combineren een positieve of therapeutische werking vaak met een negatieve, toxische werking op gedrag. 
Dat geneesmiddelen ook negatieve gedragseffecten kunnen veroorzaken is al lange tijd bekend. Een van de eerste definities van gedragstoxicologie stamt uit de jaren '6o en is afkomstig van Jonathan Cole (1960). Volgens zijn definitie verwijst de term gedragstoxicologie vooral naar een afname in subjectieve stemming en een afname in objectief gedrag na inname van een geneesmiddel. In deze definitie wordt nog geen onderscheid gemaakt tussen gedragsveranderingen die worden veroorzaakt door een directe en indirecte invloed van geneesmiddelen of drugs op neuropsychologische functies. Toch is dat onderscheid van belang. Geneesmiddelen en drugs kunnen allerlei reacties veroorzaken die op zichzelf niet gerelateerd zijn aan neuropsychologisch functioneren. Denk bijvoorbeeld aan een motorische stoornis, een allergie voor een geneesmiddel, levertoxiciteit of cardiotoxiciteit. Deze bijwerkingen kunnen zeker ook van invloed zijn op gedragsfuncties, maar deze invloed is een afgeleide van en dus indirect. De gedragstoxicologie richt zich echter primair op gedragsveranderingen die door psychofarmaca worden bewerkstelligd via een directe neurofarmacologische verandering in het brein.

De toxische effecten van psychofarmaca op gedrag kunnen sterk verschillen in aard. Zo zijn er psychofarmaca die snelheid en organisatie van informatieverwerking in de hersenen negatief beïnvloeden. De meest voorkomende bijwerking van dit type is sufheid of slaperigheid die ontstaat door de dempende werking van sommige psychofarmaca op het centrale zenuwstelsel. Dit type bijwerking wordt veroorzaakt door veel moderne geneesmiddelen, zoals kalmeringsmiddelen, slaapmiddelen, antidepressiva en antipsychotica. En slaperigheid is natuurlijk een hinderlijke en risicovolle bijwerking voor patiënten die tijdens hun medicatieperiode wel normaal willen functioneren in hun gezin, op hun werk of in het verkeer.

Een bijwerking die ook regelmatig wordt gerapporteerd bij psychofarmaca is anterograde amnesie. Anterograde amnesie houdt in, dat er geen nieuwe herinneringen kunnen worden opgeslagen. Deze geheugen effecten zijn o.m. aangetoond voor ecstasy of reguliere slaapmiddelen. Er zijn aanwijzingen dat de anterograde amnesie vooral betrekking heeft op het herinneren van expliciete gebeurtenissen en minder op impliciete, procedurele kennis, zoals hoe je veters moet strikken. In de afgelopen jaren zijn slaapmiddelen verschillende keren in verband gebracht met episodes van slaapwandelen en andere nachtelijke en 
soms gevaarlijke incidenten zoals nachtelijk eten, winkeldiefstal en zelfs autorijden waaraan de betreffende persoon geen enkele herinnering meer had.

Toxische effecten van psychofarmaca kunnen ook tot uitdrukking komen in emotionele en motivationele reacties. Onverschilligheid, sociale isolatie of apathie als gevolg waarvan gebruikers van psychofarmaca niet langer geïnteresseerd zijn in persoonlijke of maatschappelijke doelen en perspectieven. Voorbeelden van emotionele vervlakking zijn gerapporteerd voor antipsychotica, maar ook voor recreatieve drugs zoals cannabis. Het meest schrikbarende voorbeeld van dit type bijwerking stamt uit de tijd van het communisme in de Sovjet-Unie. In die tijd werden politieke tegenstanders van het Sovjet regime niet zelden opgenomen in psychiatrische gevangenissen en onderdrukt met zware doseringen antipsychotica. De politieke gevangenen omschreven deze medicamenteuze behandeling als een chemische dwangbuis of als chemische onderdrukking. Deze vorm van strafpsychiatrie werd in het Westen onder de aandacht gebracht door de Russische psychiater Koryagin (Koryagin, 1981), die daardoor ook zelf in een strafkamp belandde. Natuurlijk was hier overduidelijk sprake van onethisch gebruik van geneesmiddelen. Maar deze casus geeft wel aan dat gedragstoxicologische effecten van antipsychotica eenvoudig kunnen overheersen, afhankelijk van gebruik en dosering.

Tot de motivationele reacties behoren ook cognitieve veranderingen die kunnen leiden tot afhankelijkheid en risicogedrag, zoals bij verslavende middelen. Sinds lang wordt onderkend dat druggebruikers impulsief consumeren omdat ze cognitieve controle verliezen over hun druggebruik. Dit verlies aan controle wordt ook wel aangeduid als een stoornis in de executieve functies. Deze zogenaamde hogere, cognitieve functies spelen een rol in het plannen en reguleren van doelgericht gedrag. Deze functies worden verzorgd door de prefrontale cortex die via neuronale circuits ook verbonden is met hersengebieden die weer een belangrijke rol spelen bij motivationele en beloningsprocessen. Met andere woorden: verslavende drugs oefenen hun belonende werking uit door in te grijpen op neuronale circuits die normaal gesproken worden gestimuleerd door natuurlijke beloners zoals voedsel en seks. De neurotransmitter dopamine speelt een belangrijke rol bij gebruik en afhankelijkheid van verslavende middelen. Alle verslavende middelen leiden op directe of indirecte wijze tot een toename in dopamine spiegels in het brein. 
Herhaald gebruik kan leiden tot tijdelijke of structurele veranderingen in de dopaminerge transmissie en daarmee ook in de cognitieve controle functies.

Tenslotte zijn er ook psychofarmaca die sterk afwijkend gedrag kunnen veroorzaken, zoals agressie, paranoia of hallucinaties. Bekende voorbeelden van psychofarmaca die dit type reactie kunnen uitlokken zijn alcohol en een reeks van drugs zoals cannabis, PCP, LSD en ecstasy. Het gaat hier vaak om anekdotische reacties die niet vaak voorkomen, of alleen bij overmatig gebruik. Het is over het algemeen ook erg moeilijk om deze effecten te bestuderen in een laboratorium onder gecontroleerde omstandigheden. De bijwerkingen kunnen immers te schadelijk zijn zodat het medisch ethisch onverantwoord is om deze onder gecontroleerde omstandigheden bij mensen te onderzoeken. Kennis over deze bijwerkingen ontstaat dus via anekdotische verslagen vanuit praktijksituaties of door middel van dierexperimenteel onderzoek.

Maar ook bij reguliere geneesmiddelen wordt wel eens sterk afwijkend gedrag gerapporteerd. Een groep geneesmiddelen die de laatste jaren sterk in opspraak is geraakt, zijn de SSRI's. Dat is een groep antidepressiva die de heropname van serotonine remt en daardoor de totale beschikbare hoeveelheid serotonine in het brein verhoogt. SSRI's produceren over het algemeen nauwelijks of geen ernstige bijwerkingen. Verschillende overzichtstudies lijken echter wel aan te duiden dat het risico op zelfmoord en manie toeneemt tijdens SSRI-gebruik in een kleine groep gebruikers, vooral tijdens de eerste weken van behandeling. Om die reden heeft de Food and Drug Administration (FDA) recent een waarschuwing doen uitgaan over de behandeling met antidepressiva. Dezelfde groep geneesmiddelen is de afgelopen jaren ook in verband gebracht met ontremming en agressief gedrag. Het causale verband tussen geweldpleging en SSRI-gebruik is echter moeilijk vast te stellen vanwege het anekdotische karakter van al deze gebeurtenissen.

\section{Historie gedragstoxicologie in Maastricht}

Het vakgebied van de gedragstoxicologie heeft een lange historie aan de Universiteit Maastricht. Die begon met de oprichting van het Instituut voor Humane Psychofarmacologie (IHP) in 1986 door de 'founding father' Prof dr Jim O'Hanlon (O'Hanlon et al, 1982). Het IHP bestudeerde in het bijzonder de invloed van geneesmiddelen op rijvaardigheid. Het instituut standaardiseerde een aantal rijtests, die uitermate gevoelig 
bleken voor de negatieve invloed van sedatieve geneesmiddelen op rijvaardigheid. Deze rijtests werden uitgevoerd onder normale verkeersomstandigheden op de openbare weg onder begeleiding van een gediplomeerde rijinstructeur. Deze unieke, gestandaardiseerde rijtests werden ingezet in tientallen vergelijkende studies naar de invloed van nieuwe en oude geneesmiddelen op rijvaardigheid van gezonde vrijwilligers. Dit leidde uiteindelijk tot een kwalificering en kwantificering van effecten van een groot aantal antidepressiva, slaapmiddelen, kalmeringsmiddelen en anti-hooikoortsmiddelen op rijvaardigheid. Uit deze gegevens volgden specifieke adviezen aan artsen en psychiaters over de relatie tussen dosering van een geneesmiddel, duur van gebruik en rijgeschiktheid. Mede op basis van deze adviezen werd een internationaal categorisatiesysteem ontwikkeld voor effecten van individuele geneesmiddelen op rijvaardigheid door de International Council on Alcohol, Drugs and Traffic Safety (ICADTS). Dit categorisatiesysteem wordt tot op de dag van vandaag geraadpleegd door artsen en psychiaters en dient voor vele internationale overheden als leidraad voor wetgeving ten aanzien van geneesmiddelen in het verkeer.

Het IHP hield op te bestaan in 1997. De onderzoekslijn werd vervolgens met succes ondergebracht bij de Faculteit der Psychologie en Neurowetenschappen (FPN) en het Instituut voor Hersenen \& Gedrag. De onderzoekslijn is inmiddels stevig verankerd bij FPN en heeft sindsdien een groot aantal contractonderzoeken met de farmaceutische industrie opgeleverd. Ook werden 2 grote Europese subsidies verworven in de 5e en 6 e kaderronde van de Europese Commissie. De meeste recente subsidie stelt een Europees consortium (DRUID) van 37 partners in staat om de relatie tussen psychofarmaca, neurocognitief functioneren en ongevalrisico in het verkeer nader in kaart te brengen. Een van de hoofddoelen van DRUID is de bepaling van concentratie limieten in bloed en speeksel voor individuele geneesmiddelen en drugs.

Invloed van geneesmiddelen en drugs op rijvaardigheid.

Onderzoek naar de invloed van geneesmiddelen en drugs op rijvaardigheid wordt qua methode al 25 jaar onveranderd toegepast in Maastricht. Deze traditie bestaat kort samengevat uit het meten van de invloed van geneesmiddelen en drugs op rijvaardigheid zoals gemeten tijdens een standaard rijtest die wordt uitgevoerd onder normale verkeersomstandigheden op de openbare weg. De test kent eigenlijk maar één hoofdparameter: de standaard deviatie van laterale 
positie (SDLP). Met deze maat meten we de gemiddelde slingering waarmee een bestuurder onder invloed een vastgesteld traject aflegt op de openbare snelweg. Hoe groter de sedatieve werking van een drug of geneesmiddel, hoe groter de gemiddelde slingering. In het verleden is ook een heel scala aan parameters gemeten tijdens afname van de rijtests, maar geen enkele parameter bleek zo gevoelig voor de invloed van geneesmiddelen en drugs als SDLP. De gevoeligheid van deze parameter voor invloeden van psychofarmaca verklaart natuurlijk ook in hoge mate het succes van het Maastrichtse rijonderzoek. Daarnaast is het natuurlijk ook een zeer relevante parameter, want één van de meest voorkomende vormen van afwijkend rijgedrag onder invloed van drugs of alcohol is slingeren over de weg. Het is tamelijk uniek te noemen dat de standaard rijtest in ongewijzigde vorm is toegepast in circa 100 rijvaardigheidstudies in de afgelopen 25 jaar. In dit model werden allerlei geneesmiddelen getest zoals kalmeer-en slaapmiddelen, antidepressiva, anti-hooikoortsmiddelen, anti-epileptica en zelfs geneesmiddelen tegen malaria. Daarnaast werden ook drugs zoals cannabis en ecstasy onderzocht in het Maastrichtse rijmodel. Het grote voordeel van deze gestandaardiseerde methode is dat de effecten van individuele psychofarmaca op SDLP met elkaar kunnen worden vergeleken en ten opzichte van elkaar kunnen worden gekwantificeerd.

Is de Maastrichtse rijtest noodzakelijk?

Het Maastrichtse rijonderzoek is ook uniek omdat het in geen ander land navolging heeft. Veel collega onderzoekers vermoeden dat het Maastrichtse onderzoek ogenblikkelijk op juridische en ethische problemen zou stuiten bij hun plaatselijke medisch ethische commissie. Sommige onderzoekers zijn van mening dat het risico waaraan proefpersonen of andere weggebruikers worden blootgesteld te groot is. Een goed voorbeeld is wellicht het ecstasy onderzoek dat we vorig jaar hebben uitgevoerd in opdracht van de Europese Commissie. Ditonderzoek werd uitgevoerd met toestemming van de medische ethische commissie van de Universiteit Maastricht en later ter informatie voorgelegd aan een ethische commissie ingesteld door diezelfde Europese Commissie. Een van de commissieleden was van mening dat rijonderzoek met drugs en geneesmiddelen op de openbare weg in principe onethisch is, omdat er mogelijk ongevalrisico's aan verbonden zijn. Het commissielid was bovendien van mening dat niet alleen deelnemers aan het onderzoek moeten worden ingelicht over het de aard en het risico verbonden aan het onderzoek, maar ook alle verkeersdeelnemers die niet meedoen aan 
het onderzoek maar wel gebruik maken van dezelfde openbare weg. Hoe dat verder in zijn werk zou gaan werd er natuurlijk niet bij verteld, maar je zou kunnen denken aan bilboards langs de weg waarop kenbaar wordt gemaakt dat er experimenteel onderzoek plaatsvindt met drugs of geneesmiddelen.

Dat gaat natuurlijk veel te ver. Geen enkel geneesmiddelenonderzoek is absoluut veilig. Absolute veiligheid is ook niet de standaard waartegen het rijonderzoek moet worden getoetst. Risico's moeten minimaal zijn en in redelijke verhouding staan tot de maatschappelijke of wetenschappelijke winst die wordt behaald met de uitvoering van het rijonderzoek. Die meerwaarde van de Maastrichtse rijtest is vooral gelegen in het feit dat er na al die jaren nog steeds geen neuropsychologische test of rijsimulator bestaat die net zo gevoelig is voor drugeffecten als de Maastrichtse rijtest. Er is dus alle reden om het Maastrichtse rijonderzoek nog jaren operationeel te houden. Bovendien leert de ervaring in afgelopen 25 jaar, dat het Maastrichtse onderzoek veilig is, en zonder problemen kan worden uitgevoerd op de openbare weg onder normale verkeersomstandigheden.

\section{Een cannabis mythe}

Een van de meest controversiële stoffen waar het gaat om rijvaardigheid is cannabis. Talloze placebo gecontroleerde studies in het laboratorium laten zien dat psychologische functies zoals aandacht, concentratie, reactievermogen en besluitvorming afnemen onder invloed van cannabis. En toch leeft onder veel wetenschappers en beleidsmakers de indruk dat cannabis weinig negatieve invloed heeft op rijvaardigheid en dat bestuurders onder invloed van cannabis hier gemakkelijk voor kunnen compenseren. Maar waar is deze opvatting nu eigenlijk op gebaseerd?

Deze opvatting voert ondermeer terug naar een aantal Maastrichtse rijstudies die in de jaren '9o door oud collega's Robbe en O'Hanlon werden uitgevoerd (Robbe, 1994). Zij waren de eersten die de invloed van cannabis onderzochten in het Maastrichtse rijmodel. De verwachting vooraf was, dat cannabis een zeer negatieve invloed op rijvaardigheid zou uitoefenen. Om die reden vonden de eerste rijtests dan ook plaats op een 'veilig' stukje snelweg dat was afgesloten voor het overige verkeer. De resultaten van deze studies lieten echter zien dat deze voorzorgsmaatregel nogal overdreven was. Cannabis verhoogde weliswaar het slingergedrag van proefpersonen, maar toch niet in die 
ernstige mate die op voorhand werd verwacht. De invloed van cannabis was niet ongewoon hoog en veeleer vergelijkbaar met die van een groot aantal geneesmiddelen of een lage dosering alcohol. Vanuit dat perspectief concludeerden de Maastrichtse onderzoekers toen dat invloed van cannabis op rijvaardigheid relatief gering is.

Het is interessant om te zien hoe deze Maastrichtse conclusie later is geïnterpreteerd in de media en onder wetenschappers. Verschillende populaire media verwezen naar de Maastrichtse rijstudies om aan te tonen dat het absoluut veilig is om met cannabis achter het stuur te rijden. En altijd volgde in die context het Maastrichtse citaat dat de effecten van cannabis op rijvaardigheid relatief mild zijn. Ook in de wetenschappelijke literatuur werd met regelmaat geconcludeerd dat experimentele studies nauwelijks invloed van cannabis op rijvaardigheid lieten zien, met als belangrijkste voorbeeld de Maastrichtse rijstudies. Daardoor ontstond een situatie waarin het voor beleidsmakers erg moeilijk was om wetgeving t.a.v. cannabis in het verkeer te ontwikkelen. Dat leidde soms weer tot boze reacties van politici die nu juist heel graag het gebruik van cannabis in het verkeer willen aanpakken. Zo werden er zelfs in de Amerikaanse senaat vragen gesteld over de relevantie en betrouwbaarheid van het Maastrichtse rijonderzoek. Senator Chuck Grassley uit lowa ging zelf zover om te stellen dat cannabis onderzoek uit Nederland per definitie onbetrouwbaar moet zijn vanwege de liberale houding van de Nederlandse regering t.a.v. cannabisgebruik.

In feite blijkt uit het Maastrichtse rijonderzoek eenduidig dat slingergedrag toeneemt bij proefpersonen onder invloed van cannabis. Echter, de wijze waarop deze bevinding in de jaren ' 90 is geïnterpreteerd en gecommuniceerd heeft bijgedragen aan het beeld dat het allemaal wel meevalt met die invloed van cannabis. Toch zijn het niet alleen de Maastrichtse rijstudies die hebben bijgedragen aan deze beeldvorming. Die wordt voor een gedeelte ook bepaald door een groot aantal epidemiologische studies die geen relatie kunnen vaststellen tussen cannabisgebruik en ongevalrisico's in het verkeer. Epidemiologische studies stellen het ongevalrisico voor cannabis vast op basis van een vergelijking van de frequentie van cannabisgebruik onder bestuurders die betrokken raakten bij een verkeersongeval (de cases) en bestuurders uit de algemene rijpopulatie die niet betrokken raakten bij een verkeersongeval (de controles). Indien de frequentie van cannabisgebruik bij verkeerslachtoffers hoger is dan die in de algemene verkeerspopulatie, 
dan wordt aangenomen dat cannabis een oorzakelijke rol speelt bij verkeersongevallen. De centrale vraag is waarom de experimentele gegevens zo sterk verschillen van de epidemiologische gegevens.

Er zijn drie factoren te noemen die bijdragen aan deze discrepantie. De belangrijkste factor is wellicht de wijze waarop gebruik van cannabis in het verkeer wordt vastgesteld. Het merendeel van de epidemiologische studies stelden cannabisgebruik vast door meting van $\mathrm{THC}-\mathrm{COOH}$ in urine. THC-COOH is een metaboliet van de actieve stof in cannabis, delta-9-tetrahydroxycannobiol (THC). Maar THC-COOH is een inactieve stof die bovendien weken na cannabisgebruik op te sporen is in urine. Uit de aanwezigheid van THC-COOH in urine kan dus niet worden afgeleid dat een bestuurder ook daadwerkelijk onder invloed was van cannabis ten tijde van het ongeval. Het is dus van belang dat in epidemiologische studies de aanwezigheid van THC in het bloed van slachtoffers en verkeersdeelnemers wordt gemeten. Alleen dan kan het ongevalrisico voor cannabis betrouwbaar worden vastgesteld (Ramaekers et al, 2004).

Ook wordt in epidemiologische studies zelden gekeken naar de relatie tussen THC-concentraties in bloed en ongevalrisico, terwijl het toch voor de hand ligt dat de risico's toenemen bij hogere concentraties. Als met deze factor wel rekening wordt gehouden blijken experimentele en epidemiologische gegevens lang niet meer zo ver uit elkaar te liggen. Uit verschillende studies komt duidelijk naar voren dat zowel gedragstoxiciteit en ongevalrisico onder invloed van THC toenemen bij toenemende THC concentraties in bloed. Vanaf concentraties boven 5ng/ $\mathrm{mL}$ in bloed (plasma) is deze toename in gedragstoxiciteit ook statistisch significant. Dat betekent automatisch, dat THC concentraties lager dan $5 \mathrm{ng} / \mathrm{mL}$ geen risico op een verkeersongeval opleveren (Ramaekers et al, 2006; Grotenhermen et al, 2008). Deze studies naar concentratie effect relaties hebben de afgelopen jaren een belangrijke bijdrage geleverd aan een veranderde beeldvorming bij wetenschappers en beleidsmakers en aan een wetenschappelijke onderbouwing voor grenswaarden voor cannabis (THC) in het verkeer.

En er is het fenomeen tolerantie. Uit dierexperimenteel onderzoek is bekend dat de binding van THC aan cannabis receptoren afneemt na herhaald gebruik. Uit humane studies is gebleken dat de invloed van cannabis op cognitief functioneren vooral optreed bij sporadische 
gebruikers, maar dat deze effecten niet meer optreden bij ervaren, dagelijkse gebruikers. Deze laatste groep ontwikkelt dus gewenning of tolerantie voor de negatieve invloed van cannabis op cognitie of rijvaardigheid. Uit onderzoek blijkt ook, dat ervaren rokers bijna dagelijks autorijden onder invloed van cannabis, terwijl onervaren rokers dat zelden of nooit doen. Het gevolg zou dus kunnen zijn dat de ervaren rokers oververtegenwoordigd zijn in de algemene verkeerspopulatie terwijl de onervaren rokers juist oververtegenwoordigd zijn onder verkeersslachtoffers. Netto levert dit geen verhoging van het ongevalrisico op voor de groep cannabisgebruikers als geheel, maar dat sluit niet uit dat een verhoogd ongevalrisico wel kan bestaan voor de subgroep van onervaren gebruikers (Ramaekers et al, 2009).

Uit bovenstaande voorbeelden blijkt heel duidelijk, dat resultaten in experimentele en epidemiologische studies door meerdere factoren bepaald kunnen worden dan het gebruik van cannabis alleen. Andere factoren zoals dosering en frequentie van cannabisgebruik spelen evenzeer een rol. De uitdaging voor toekomstig onderzoek naar de invloed van cannabis op rijvaardigheid bestaat er dan ook uit om deze factoren te betrekken in toxicologische, epidemiologische en experimentele studies, zodat wetenschappelijke coherentie en evidentie die nodig zijn voor een genuanceerde beeldvorming en regelgeving op het gebied van cannabis in het verkeer zullen toenemen.

Een ecstasy mythe

Een van de meeste controversiële stoffen waar het gaat om effecten op geheugen is ecstasy. Ecstasy heeft een slechte reputatie en staat te boek als een neurotoxische stof die het brein onherstelbaar kan beschadigen. Maar waarom duiken ecstasygebruikers dan niet massaal op in de gezondheidszorg met hersengerelateerde klachten?

Een van de meest spraakmakende onderzoeken op dit gebied werd meer dan 10 jaar geleden gepubliceerd door de onderzoeksgroep van Ricaurte (Hatzidimitriou, 1999). Deze onderzoekers lieten zien dat een eenmalige toediening van ecstasy aan doodshoofdaapjes grote schade veroorzaakt aan de vertakkingen van serotonerge hersencellen. Bovendien lieten deze onderzoekers zien, dat deze hersenschade zeven jaar later slechts gedeeltelijk was hersteld. Op basis van dit onderzoek werd onder meer geconcludeerd dat ecstasy een neurotoxische stof is die een groot gezondheidsrisico kan veroorzaken voor gebruikers. Niet verwonderlijk 
dus dat de media veel interesse toonde voor dit onderwerp en uitgebreid berichtte over de schadelijke effecten van ecstasy op het menselijk brein.

Maar dierexperimentele bevindingen kunnen niet automatisch worden gegeneraliseerd naar mensen. Zo weten we niet of de dosering van ecstasy die aan de doodshoofdaapjes werd gegeven vergelijkbaar is met de doseringen die jongeren gebruiken in het uitgaanscircuit. De opname en beschikbaarheid in het brein van psychofarmaca kan sterk verschillen tussen mens en dier en ook de manier waarop het brein reageert op psychofarmaca kan in de mens sterk afwijken t.o.v. dieren. Zulke verschillen zijn ook al zichtbaar tussen diersoorten onderling. Zo is de neurotoxische werking op het serotonerge systeem aangetoond bij aapjes en ratten, maar niet bij muizen. Bij muizen blijft het serotonerge systeem na toediening van ecstasy intact, maar treedt er wel toxiciteit op in dopaminerge system. De neurotoxiciteit van ecstasy bij mensen kan dus niet zuiver en alleen worden vastgesteld op basis van dieronderzoek alleen. Er moet ook humaan onderzoek aan te pas komen.

Maar humaan onderzoek kent ook zijn beperkingen. We kunnen niet een stukje van de hersenen verwijderen bij ecstasygebruikers en dat vervolgens onder de microscoop leggen. Wel kunnen we onderzoeken of er indirect bewijs bestaat voor neurotoxische effecten van ecstasy bij mensen. Zo kunnen we bij mensen bijvoorbeeld het functioneren van het brein bestuderen. Als ecstasy daadwerkelijk het serotonine systeem beschadigt in het menselijke brein, dan is het ook aannemelijk dat er toxiciteit zal optreden op gedragsniveau. Serotonine is een belangrijke neurotransmitter in het brein die betrokken is bij allerlei psychologische functies zoals aandacht, concentratie, slaap en geheugen. Als het serotoninesysteem minder goed functioneert door ecstasygebruik, dan zullen ook deze psychologische functies achteruitgaan. Om die reden zijn de afgelopen 10 jaar talloze studies verricht door wetenschappers uit de hele wereld naar de invloed van ecstasy op psychologische functies. Veel van deze studies lieten zien dat het korte en lange termijn geheugen van ecstasygebruikers minder is in vergelijking tot personen die nooit ecstasy hebben gebruikt. Het gaat hier om de geheugencapaciteit van ecstasygebruikers die op het moment van testafname niet onder invloed zijn. De geheugenvermindering is vooral meetbaar bij grootgebruikers van ecstasy, maar ook bij voormalige ecstasygebruikers. Op basis van deze studies heeft menig onderzoekers al geconcludeerd dat een verminderde geheugenfunctie bij ecstasygebruikers een direct gevolg 
kan zijn van de neurotoxische werking van ecstasy op het brein, en dat deze verandering structureel en permanent van aard is.

Maar deze conclusie is zeer omstreden en wordt door verschillende wetenschappers betwist. Ze wijzen er op dat veel van de zogenaamde ecstasygebruikers ook regelmatig andere psychofarmaca gebruiken zoals cannabis, amfetaminen en alcohol. Het is dus heel goed mogelijk dat juist een van deze stoffen, of het combinatiegebruik, de werkelijke reden is voor de afname in geheugenfunctie bij ecstasygebruikers. Een verklaring kan ook gezocht worden in bestaande verschillen in psychopathologie en leefstijl van druggebruikers en niet-gebruikers. Het is bij deze vergelijkende studies eigenlijk onmogelijk om een groot aantal alternatieve verklaringen voor de geheugenachteruitgang bij ecstasygebruikers uit te sluiten. Om die reden kan op basis van deze studies niet worden vastgesteld dat ecstasy tot permanente geheugenschade leidt. Deze studies laten ook zeker niet zien dat een een malige dosering van ecstasy al tot grote schade in het brein kan leiden. En toch wordt dat door dierexperimenteel onderzoek gesuggereerd.

Wat we nodig hebben is controle. Controle over al die alternatieve factoren die ook een verklaring kunnen vormen voor de geheugenachteruitgang van ecstasygebruikers. Die controle kan worden verkregen in studies waarin ecstasy in placebo gecontroleerde studies wordt toegediend aan proefpersonen. We kunnen geheugenprestaties meten van proefpersonen die onder invloed zijn van ecstasy en die vergelijken met hun eigen geheugenprestatie onder invloed van een neppil. We hebben te maken met 2 metingen bij dezelfde proefpersoon die plaatsvinden onder volstrekt gelijke omstandigheden. Er is maar één factor die verschilt over beide metingen: de toediening van ecstasy en placebo. Ook hier speelt ethiek overigens weer een belangrijke rol. Tegenstanders noemen het onethisch om een stof die verdacht wordt van neurotoxiciteit gecontroleerd toe te dienen aan proefpersonen. Voorstanders wijzen juist op de wetenschappelijke meerwaarde van dit onderzoek. Die meerwaarde wordt overigens ook erkend door de medisch ethische commissie van de Universiteit Maastricht. Die heeft het Maastrichtse ecstasy onderzoek altijd positief beoordeeld, onder de voorwaarde dat ecstasy alleen wordt toegediend aan proefpersonen die al ervaring hebben met ecstasygebruik. En dat is ook begrijpelijk, want we willen geen personen aanzetten tot druggebruik of blootstellen aan risico's die zij zelf niet eerder hebben genomen. 
Een voorbeeld van een placebo gecontroleerde studie met ecstasy die werd uitgevoerd in ons laboratorium aan de Universiteit Maastricht wil ik hier graag even vermelden (Kuypers \& Ramaekers, 2005). Deze studie laat heel duidelijk zien, dat dierexperimentele bevindingen niet zomaar vertaald kunnen worden naar de mens. In deze studie kregen ecstasygebruikers een eenmalige dosering van ecstasy (75mg 3,4-methyldioxymethamfetamine) en placebo toegediend in 2 opeenvolgde condities. Geheugen prestatie werd gemeten middels een woorden leertaak tussen 1-2 uur na inname van ecstasy en placebo en een dag na inname toen de stoffen niet langer werkzaam waren. Uit de resultaten bleek heel duidelijk dat een eenmalige dosering van ecstasy de geheugen prestatie deed afnemen op het moment dat proefpersonen onder invloed waren. Hun geheugenfunctie herstelde zich ook weer tot hun normale nivo een dag na inname toen ecstasy niet langer actief was in het brein. Deze studie bevestigde eigenlijk voor het eerst dat er een oorzakelijke relatie bestaat tussen ecstasy gebruik en geheugenachteruitgang. Maar nog belangrijker is de bevinding dat deze geheugenachteruitgang van tijdelijk aard is. Met andere woorden, er is op basis van deze studie geen reden om aan te nemen dat een eenmalige dosering ecstasy kan leiden tot permanente schade aan het geheugen. Dat is een belangrijke bevinding die haaks staat op eerdere conclusies die werden getrokken op basis van dierexperimenteel onderzoek of op basis van vergelijkend onderzoek tussen ecstasygebruikers en niet-gebruikers.

Helaas krijgt deze bevinding slechts weinig erkenning bij de meeste collega wetenschappers en wordt deze studie meestal genegeerd in wetenschappelijke artikelen over langdurige effecten van ecstasy op geheugen. Datheeft niets met de kwaliteitvan het Maastrichtseonderzoek te maken, maar alles met een blinde vlek voor placebo gecontroleerd onderzoek bij veel collega ecstasyonderzoekers. Maar misschien komt daarin binnenkort wel verandering. Onze studie is recentelijk opgenomen in een standaard leerboek over psychofarmacologie (Julian, 2008). Daarin wordt het belang van deze studie gelukkig wel herkend en overgedragen aan studenten en docenten psychofarmacologie.

Neurofarmacologie van gedragstoxiciteit

De gedragstoxicologie richt zich ook op neurofarmacologische mechanismen die ten grondslag liggen aan de effecten van drugs en geneesmiddelen op gedrag. Ook in dat opzicht kunnen placebo gecontroleerde, mechanistische studies van grote meerwaarde zijn. Ik wil hier kort een aantal voorbeelden noemen van recent en toekomstig 
onderzoek op dit vlak. Een goed voorbeeld van een mechanistische aanpak zijn een aantal door NWO gesubsidieerd projecten naar farmacologische mechanismen die ten grondslag liggen aan de geheugenachteruitgang door cannabis en ecstasy. In deze projecten wordt onderzocht of geheugenachteruitgang gerelateerd aan cannabis of ecstasy kan worden voorkomen of opgeheven door farmacologische blokkade van specifieke receptoren, neurotransmitters of andere systemen. Een succesvolle blokkade van de geheugenachteruitgang betekent automatisch ook identificatie van het onderliggende neurofarmacologische proces.

Zo heeft onze onderzoeksgroep recentelijk een studie afgerond waarin de bijdrage van een tweetal specifieke serotonerge receptoren aan de geheugeneffecten van ecstasy werd onderzocht. Er werd verwacht dat proefpersonen onder invloed van ecstasy slechter zouden presteren op deze geheugentaak in vergelijking tot placebo. Deze verwachting werd ook bevestigd door de resultaten van het onderzoek. Onder invloed van ecstasy leerden de proefpersonen minder woorden. Ook werd duidelijk, dat dit geheugenverlies kan worden voorkomen door proefpersonen voor te behandelen van een $5 \mathrm{HT} 2$ antagonist. Na combinatiegebruik van een $5 \mathrm{HT} 2$ antagonist en ecstasy waren de geheugenprestaties weer vergelijkbaar met die tijdens placebo. Daaruit kan worden afgeleid dat de geheugenachteruitgang die onder invloed van ecstasy ontstaat wordt veroorzaakt door stimulatie van $5 \mathrm{HT} 2$ receptoren in het brein.

Ook placebo gecontroleerde, farmacologische fMRI studies zijn zeer geschikt om veranderingen in neurale netwerken te identificeren die optreden onder invloed van psychofarmaca. Zo kunnen op basis van farmaco-fMRI projecten niet alleen neurale netwerken worden geïdentificeerd die betrokken zijn bij de het uitvoeren van geheugen. Ook kunnen we de invloed van psychofarmaca op dit neurale netwerk visualiseren. In een recente farmaco-imaging studie konden we bijvoorbeeld een relatie leggen tussen specifieke hersengebieden en prospectieve geheugeneffecten van ecstasy. Prospectief geheugen verwijst naar het zich herinneren van toekomstige intenties, zoals naar de winkel gaan, op tijd medicijnen innemen, een collega bellen etc. Uit de resultaten bleek dat proefpersonen tijdens uitvoering van deze taak een aantal gebieden actief betrokken waren en dat op prospectieve momenten specifieke hersengebieden (de inferieure parietale lobules) werden gedeactiveerd. Onder invloed van ecstasy waren proefpersonen echter minder in staat om de hersengebieden in de parietale cortex 
te remmen waardoor ze meer prospectieve geheugenfouten maakten (Ramaekers et al, 2009).

Mechanistische studies bieden een kans om specifieke gedragstoxicologische effecten van psychofarmaca op neuraal of farmacologisch niveau nader te bestuderen. In bovengenoemde voorbeelden staan vooral geheugenprocessen centraal, maar het concept kan in principe toegepast worden bij onderzoek naar allerlei psychologische functies die door psychofarmaca worden beïnvloed zoals aandachtfuncties of impuls controle.

Aandachtproblemen spelen bijvoorbeeld een grote rol bij het gebruik van anti-hooikoortsmiddelen. Anti-hooikoortmiddelen blokkeren actief de $\mathrm{H}_{1}$ receptor in het brein en veroorzaken daardoor sufheid en slaperigheid. Sommige anti-hooikoortsmiddelen lijken echter geen slaperigheid te veroorzaken, omdat ze niet actief zijn in het brein. De reden hiervoor is onduidelijk. Mogelijk heeft dit verschil te maken met de mate waarin deze stoffen via een transportpomp weer uit het brein worden verwijderd. Om deze hypothese te toetsen zullen we in een toekomstige studie deze transportpomp blokkeren met een farmacon, waardoor in theorie ook sufheid en slaperigheid zou moeten optreden bij nietsedatieve anti-hooikoortsmiddelen.

Impuls controle speelt bijvoorbeeld een centrale rol bij verslaving. Interessant is in deze context of het gebruik van psychoactieve stoffen kan leiden tot een toename in impulsief gebruik van deze stoffen en bij welke personen een verlies van impuls controle zal leiden tot afhankelijkheid. Impuls controle wordt gemoduleerd door dopaminespiegels in de prefrontale cortex. De hoeveelheid dopamine in het brein is in sterke mate genetisch bepaald. De uitdaging bestaat daaruit om deze hypothetische relatie tussen drug gebruik, impuls controle en genetische predispositie voor dopaminerge activiteit nader te onderzoeken. We zijn dan ook zeer verheugd dat onze onderzoeksgroep recentelijk een forse subsidie heeft ontvangen van ZonMw om deze relatie nader te bestuderen in een placebo gecontroleerde studie waarin door toediening van cannabis en cocaïne een hypodopaminerge en hyperdopaminerge staat experimenteel wordt gecreëerd in proefpersonen. Deze studie kan een waardevolle bijdrage leveren aan gedragstoxicologisch onderzoek op het domein van verslaving en is een goed voorbeeld van een mechanistische, placebo gecontroleerde studie met psychofarmaca. 


\section{Woorden van dank}

Hoogleraar wordt je niet in je eentje. Er zijn tal van personen die een belangrijke bijdrage hebben geleverd aan het gedragstoxicologische onderzoek in Maastricht waardoor deze bijzondere leerstoel mogelijk werd.

De onderzoekstraditie van de gedragstoxicologie voert terug naar de oprichting van het Instituut voor Humane Psychofarmacologie zo'n 25 jaar geleden. Veel van de onderzoekers van het eerste uur zijn als groep blijven samenwerken en recentelijk weer verenigd in de capgroep Neuropsychologie en Psychofarmacologie bij de faculteit Psychology and Neuroscience. Deze mensen vormen al jaren het kloppend hart van het 'Drugs \& Driving' onderzoek in Maastricht. Mijn dank gaat dan ook uit naar Wim Riedel, Annemiek Vermeeren, Eric Vuurman, Anita van Oers, Cees van Leeuwen en Henk en Irma Brauers. Het is uniek, dat deze groep al zolang met elkaar samenwerkt, in wat zo langzamerhand wel een familiebedrijf kan worden genoemd.

Ook wil ik natuurlijk de nieuwe generatie onderzoekers graag bedanken voor hun inzet en toewijding die ze in de afgelopen jaren hebben getoond bij het opzetten en uitvoeren van hun gedragstoxicologische onderzoeken. Ik bedank Eef Theunissen, Kim Kuypers, Marleen Wingen, Caroline Lamers, Wendy Bosker, Silke Conen, Katja Bakker, Tim Leufkens en Peter van Ruitenbeek voor hun enthousiasme en toewijding tijdens onze samenwerking. Daarnaast dank ik alle andere collega's binnen de capgroep Neuropsychogie en Psychofarmacologie voor hun geduld met mij als voorzitter en natuurlijk voor de prettige samenwerking.

De laatste woorden van mijn rede gaan uit naar mijn familie, een kleine gemeenschap bestaande uit ouders, schoonmoeder, broer, 2 schoonbroers, 1 schoonzus en natuurlijk de vrienden die we voor het gemak ook maar oom en tante noemen. In onze gemeenschap speelt gedragstoxiciteit gelukkig geen rol, maar wel respect, plezier en steun aan elkaar.

Tenslotte Judy, Arthur en Aldrik. Het is altijd weer een plezier om na een dag vol gedragstoxiciteit terug te keren op ons vertrouwde honk. Ik geniet van onze momenten samen en kijk uit naar wat de toekomst ons nog zal brengen.

Ik heb gezegd. 


\section{Referenties}

Cole JO (1960) Behavioral toxicity, In: Uhr L, Miller JG (eds) Drugs and behavior. John Wiley \& Sons, New York.

Grotenhermen F, Leson G, Berghaus G, Drummer OH, Krüger HP, Longo M, Moskowitz H, Perrine B, Ramaekers JG, Smiley A, Tunbridge R (2007) Developing limits for driving under the influence of cannabis. Addiction 102:1910-1917

Hatzidimitriou G, McCann UD, Ricaurte GA (1999) Altered serotonin innervation patterns in the forebrain of monkeys treated with (+/-)3,4-methylenedioxymethamphetamine seven years previously: factors influencing abnormal recovery. J Neuroscience 19: 5096-107

Julian RM, Advokat CD, Comaty JE (2007) A primer of drug action. A Comprehensive Guide To The Actions, Uses, And Side Effects Of Psychoactive Drugs, 11th edition, Worth Pub, ISBN-10: 1429206799

Koryagin A (1981) Unwilling patients. The Lancet, a pril 11, 821-824

Kuypers KPC, Ramaekers JG (2005) Transient memory impairment after a single dose of 3,4-methylenedioxymethamphetamine (MDMA). Journal of Psychopharmacology 19: 633-639

O'Hanlon JF, Haak TW, Blaauw GJ, Riemersma JB (1982) Diazepam impairs lateral position control in highway driving. Science 217:79-81.

Ramaekers JG, Berghaus G, Van Laar M, Drummer OH (2004). Dose related risk of motor vehicle crashes after cannabis use. Drug and Alcohol Dependence 73:109-119

Ramaekers JG, Moeller MR, Van Ruitenbeek P, Theunissen EL, Schneider E, Kauert G (2006) Cognition and motor control as a function of delta9-THC in serum and oral fluid: limits of impairment. Drug and Alcohol Dependence 85: 114-122

Ramaekers JG, Kuypers KPC, Wingen M, Heinecke A, Formisano E (2009) Involvement of inferior parietal lobules in prospective memory impairment during acute MDMA (ecstasy) intoxication: an event related fMRI study. Neuropsychopharmacology 34: 1641-1648 
Ramaekers, Kauert G, Theunissen EL, Toenness SW, Moeller MR (2009) Neurocognitive performance during acute THC intoxication in heavy and occasional cannabis users, J Psychopharmacology 23: 266-277

Robbe HWJ (1994) Influence of marijuana on driving. Institute for Human Psychopharmacology, University of Limburg, Institute for Human Psychopharmacology, University of Limburg 
